\title{
Nota de Abertura ${ }^{1}$
}

\author{
Mário Barroca \\ Subdiretor da FLUP
}

O mais célebre telegrama das últimas décadas, emitido em 1974 - tempo em que ainda se usavam telegramas... -, dizia apenas, e laconicamente, "Fui para a Patagónia". Com ele Bruce Chatwin despedia-se do Sunday Times, onde era jornalista (depois de um percurso pela Sotheby's, onde fora responsável pela secção de arte impressionista), e partia para esse “Mundo do fim do Mundo”, como lhe chamou Luis Sepúlveda. Fruto dessa viagem - de Chatwin - resultou o seu Na Patagónia, editado em 1977, um livro fascinante que ajudou a reescrever o género da literatura de viagem e a conferir-lhe uma nova visibilidade no âmbito da Literatura. Quem não se recorda das mágicas palavras com que Bruce Chatwin começa o seu relato, invocando o "Armário Mágico" ou “Armário de Maravilhas” de sua avó, onde se conservava a relíquia trazida por um seu antepassado, o tio-bisavô Charley Milward:

Na sala de jantar da minha avó havia um aparador com portas de vidro e dentro desse aparador um pedaço de pele. Era apenas um bocadinho, mas espesso e coriáceo, com manchas de pêlo avermelhado e rijo. Estava preso por um alfinete enferrujado a um postal onde mal se distinguia qualquer coisa escrita a tinta preta, mas, na época, eu era demasiado miúdo para saber ler.

- O que é aquilo?

- Um pedaço de brontossauro. (Chatwin 2002: 9)

E assim começa o livro que revolucionou o género, se assim se pode dizer, da Literatura de Viagem. Pouco interessa que, afinal, o pedaço de pele não fosse de um brontossauro, mas sim de uma preguiça gigante, como o próprio Chatwin haveria de esclarecer no primeiro texto publicado em Anatomia da Errância (2008: 14). Esse brontossauro, resultado de um equívoco, ficou gravado na nossa memória...

Nos tempos que correm, em que a deslocação passou a fazer parte intrínseca de todos nós, ocidentais (com Erasmus, Ryanair's e outras realidades do nosso quotidiano), os relatos de viagem ganharam uma actualidade especial. Podemos falar de literatura de viagem em múltiplas acepções. A de Bruce Chatwin, ou de Luis Sepúlveda, 
ou de Paul Theroux, que implicam a deslocação para cenários diferentes, alguns exóticos, outros simplesmente distintos. As viagens à Índia de Alberto Moravia, de Gonçalo M. Tavares ou de Almeida Faria. Ou as viagens à Síria, de Agatha Christie, certamente mais conhecida por outro género literário... Viagens como a de Fernão de Magalhães, iniciada em 1519, cujo quinto centenário comemoramos este ano. Ou as viagens científicas, como a de Charles Darwin, no Beagle, pela América do Sul, que mudou, de forma indelével, a ciência e a nossa percepção do mundo. Enfim, as viagens em busca do outro. E isso, nos tempos que correm, é particularmente importante, porque é pedagógico, é civilizacional. Ajuda-nos a compreender os outros, a sermos tolerantes, a aceitar a diferença, a sermos Cidadãos. Por muito pouco que isso possa parecer, é muito importante neste mundo dominado por twitter's cretinos e por populismos serôdios, tão perigosos.

Mas o tema também invoca outras viagens, que não serão tão “exóticas”, porque não implicam deslocações extremas. Estou a pensar, por exemplo, nesse relato, igualmente marcante e fracturante, que foi On the Road, na tradução portuguesa Pela Estrada Fora, de Jack Kerouac, que nos ajudou a descobrir a errância e a poesia da errância, percorrendo e desvendando o território norte americano. Um relato que moldou a Beat Generation e as gerações que se seguiram.

Mas também temos outras viagens, mais interiores. Não teremos, certamente, de invocar aqui Charles Baudelaire ou Timothy Leary para compreender onde chegaram essas viagens interiores...

O tema da literatura de viagem não se circunscreve, nos nossos dias, apenas à palavra escrita. Robert Frank, infelizmente desaparecido há umas escassas semanas, deixou-nos um livro não menos marcante - The Americans - publicado em 1958, com um texto introdutório assinado precisamente por Kerouac, e que é, certamente, um dos mais seminais livros da história da fotografia contemporânea.

E a literatura de viagem plasma-se, também, nesse novo género do «livro de esquissos de viagem», parente afastado da “novela gráfica”, de que temos, entre nós, um dos nomes cimeiros em Portugal, Eduardo Salavisa.

Perdoem-me este arrazoado de ideias e a audácia de as vir pronunciar aqui, perante tão distinta audiência. Elas procuraram, apenas, demonstrar como o género da Literatura de Viagem, de tão polifacetado que é, se presta a ser abordado em perspectivas tão diferentes e tão ricas. Estou certo que, nesta iniciativa, $\varepsilon m$ torno de Viagens e Outras Deslocações serão percorridas por muitas outras veredas que não as que eu aqui referi. Porque a viagem pertence a cada um de nós, é gizada por cada um de nós, e espelha aquilo que cada um de nós é. E, por isso, ela pode e deve ser trilhada por múltiplas veredas. 


\section{Nota}

' $O$ texto que se segue foram as breves palavras de boas vindas proferidas, enquanto representante da FLUP, na iniciativa Em torno de Viagens e de Outras Deslocações do Instituto de Literatura Comparada Margarida Losa. Entendeu a organização do evento que faria algum sentido publicar neste volume de estudos, o que me deixa lisonjeado e reconhecido, ainda que tal cortesia não ajude a dissipar totalmente as dúvidas que me assolam... Lido a 2 de outubro de 2019 , algumas das suas passagens revelam-se hoje, em tempos de pandemia e de confinamentos, singularmente distantes. E, no entanto, apenas se passou um ano.

\section{Bibliografia}

Chatwin, Bruce (2002), Na Patagónia, Lisboa, Quetzal Editores.

-- (2008), Anatomia da Errância, Lisboa, Quetzal Editores. 